\title{
Tata Kelola Administrasi dan Pengembangan Desa Inovatif Berbasis Riset
}

\author{
Tunggul Prasodjo \\ STISIP 17-8-1945 Makassar \\ e-mail: tunggul.prasodjo@gmail.com
}

\begin{abstract}
ABSTRAK
Riset dan pembangunan merupakan dua hal yang harus benar-benar diperhatikan oleh lembaga pemerintah untuk menunjang pelaksanaan pemerintahan. Khususnya pelaksanaan pemerintah desa yang merupakan ujung tombak dari kebijakan pemerintah secara nasional harus mampu menggugah potensi lokal sesuai dengan fungsinya dalam melaksanakan otonomi yang diberikan. Kajian ringkas ini berusaha untuk mengungkap baik secara teoretis sekaligus menggugah kesadaran akan pentingnya riset dalam menumbuhkembangkan potensi desa agar menjadi desa dengan di dalamnya muncul masyarakatmasyarakat yang kreatif dan inovatif. Masyarakat yang inovatif sulit muncul dengan sendirinya apabila tidak dipahami dan diberikan ransangan yang sesuai dengan kultur sosial budayanya, maka riset, khsusunya riset sosial yang mengarah ke R\&D paling tidak tepat sebagai bidik perubahan.
\end{abstract}

Kata Kunci: Tata Kelola, Administrasi, Inovatif, R\&D

\begin{abstract}
Research and development are two things that should really be considered by government agencies to support the implementation of government. Particularly the implementation of village government which is the spearhead of the national government policy must be able to arouse local potential in accordance with its function in implementing the given autonomy. This concise study seeks to reveal both theoretically and awaken awareness of the importance of research in fostering the potential of villages to become villages with emerging creative and innovative communities. Innovative societies are difficult to emerge by themselves if they are not understood and given appropriate stimulation to their social culture, then research, especially social research leading to $R \& D$, is at least appropriate as aims of change.
\end{abstract}

Keywords: Governance, Administration, Innovative, $R \& D$

\section{PENDAHULUAN}

Pernah diadakan lomba guru kreatif, salah satu tema yang berhasil mendapatkan penghargaan terbaik adalah "one student one laptop", yang bertujuan untuk mengembangkan melek teknologi pada siswa. Tema ini menjadi tren dikarenakan pada waktu itu laptop baru mulai muncul dan hanya orang-orang tertentu yang memilikinya, kondisi yang sangat berbeda dengan saat ini, sehingga kemungkinan besar tema ini tidak akan lagi mendapatkan perhatian seperti sebelumnya. 
Bagaimana dengan adanya sebuah wacana yang pernah juga muncul yaitu "Satu Desa Satu Doktor", bagi penulis hal ini pada dasarnya tetap sangat relevan dengan kebutuhan untuk membangun desa yang berbasis kajian mendalam, tentu salah satunya dilakukan berbasis research. Mengapa desa yang perlu diutamakan? Lingkup yang paling cepat dikelola baik secara administratif, dan kebijakan hasil penelitian untuk dikembangkan bagi kesejahteraan masyarakat yang lebih cepat harus dimulai pada spasial yang terbatas dan lebih kecil, salah satunya yaitu di tingkat desa. Sehingga hasil riset yang diadakan akan lebih praktis untuk pembangunan masyarakat sesuai dengan kebutuhan.

Wacana dan harapan ini sebenarnya cukup sulit untuk dilakukan, karena sampai saat ini pengelola kebijakan publik (pemerintah) masih jarang menggunakah hasil riset sebagai bagian dari dasar kebijakan. Mungkin dinilai terlalu teoretis, meskipun pada dasarnya anggapan tersebut salah. Adanya anggapan bahwa hasil penelitian lebih mengarah hanya pada pengembangan ilmu pengetahuan dan sekedar mejawab adanya rasa ingin tahu, maka hasil penelitian ilmiah jarang digunakan untuk menjadi kebijakan yang praktis.

Kembali pada wacana satu desa satu doktor, kesinambungan dari ide tersebut mengarahkan pada wacana strategis yaitu "Pengelolaan Desa Berbasis Riset", yang tentunya mengarah pada adanya nilai akademis untuk membangun desa yang selama ini banyak diabaikan. Seolah nilai akademis hanya untuk mereka yang berprofesi di perguruan tinggi sementara kebijakan desa tidak ada hubungannya dengan nilai akademis tersebut. Tujuannya dengan demikian tidak lain adalah untuk menjembatani putusnya arti penting kajian akademis dengan praktik di lapangan yang dimulai dari spasial yang lebih kecil dan paling mungkin untuk dikembangkan sebaik mungkin secara praktis.

Salah satu keunggulan dari pengelolaan desa yang berlandaskan pada riset adalah diharapkannya munculnya desa-desa inovatif. Karena dengan melakukan riset paling tidak akan ditemukan keunggulan-keunggulan loka dari desa yang bersangkutan. Desa inovatif sendiri dapat didefinisikan sebagai desa yang mampu memanfaatkan sumber daya desa dengan cara baru. Berdasar definisi terebut, desa inovatif merupakan implementasi dari konsep pengembangan ekonomi lokal (PEL) yang mendasarkan pertumbuhannya pada endogenous development, pengembangan desa yang benar-benar bertumpu pada potensi sumber daya yang dimilikinya. Pengembangan desa inovatif memerlukan peran serta aktif dari berbagai elemen, yaitu unsur-unsur kelembagaan desa dan daerah, akademisi (perguruan tinggi), pengusaha, perbankan, dan lembaga penelitian dan pengembangan (Jati Dian, P, dkk, TT: 3).

Merujuk pada adanya peran penting perguruan tinggi dan lembaga penelitian dan pengembangan, jelas kaitannya dengan fungsinya sebagai pelaku riset dalam menemukan apa yang harus dilakukan guna mengembangkan desa inovatif tersebut. Fungsi administrasi yang mengelola dan mengatur segala kebijakan juga tidak kalah pentingnya, sehingga apa yang ditawarkan dalam kajian ringkas ini dengan "Penguatan Tata Kelola Administrasi dalam Membangu Desa Inovatif Berbasis Research” akan mendapatkan momentumnya.

\section{Tata Kelola Administrasi dalam Mengembangkan Desa Inovatif}

Menurut Peraturan Mentri dalam Negeri Republik Indonesia No 1 Tahun 2016 tentang Pengelolaan Aset Desa pada pasal 1 dijelskan bahwa desa adalah kesatuan masyarakat hukum 
yang memiliki batas wilayah yang berwenang untuk mengatur dan mengurus urusan pemerintahan, kepentingan masyarakat setempat berdasarkan prakarsa masyarakat, hak asal usul, dan/atau hak tradisional yang diakui dan dihormati dalam sistem pemerintahan Negara Kesatuan Republik Indonesia.

Adanya otonomi daerah, membantu Pemerintah Desa dalam melakukan improvisasi kinerja dan program-program yang telah di tentukan bisa dijalankan dengan maksimal. Otonomi tersebut memberi peranan seutuhnya pada Pemerintah Desa dalam mengatur rumah tangga sendiri dengan tetap berpegang teguh pada kearifan lokal yang dimiliki masyarakat tersebut, karena masyarakat adalah unsur yang paling mendasar terciptanya desayang merupakan pemerintahan yang paling terkecil (Indrawan, 2016: 5066).

Meskipun demikian pada dasarnya, desa dengan segala programnya yang harus memperhatikan local genius-nya, tetap merupakan kepanjangan untuk mewujudkan programprogram nasional. Hanya saja potensi lokal dalam penyelenggaraaannya menjadi pijakan pelaksanaan program. Apabila demikian, maka tugas dan fungsi dari pembagian wilayah administrasi di desa harus benar-benar melaksanakan fungsinya dengan baik, sehingga tujuan nasional dalam mengembangkan masyarakat desa dapat berjalan sebaik-baiknya.

Pelaksanaan administrasi pemerintahan Desa menurut Indrawan (5067) adalah suatu proses penyelenggaraan adminstrasi Pemerintah Desa dalam meningkatkan keberhasilan program pemerintah maupun dalam upaya menggerakkan partisipasi masyarakat dalam pembangunan desa, karena selain melaksanakan berbagai program pemerintah pusat, Pemerintah Desa juga dituntut untuk dapat melayani masyarakat yang berada diwilayahnya guna melaksanakan bidang pemerintahan, bidang kesejahteraan dan bidang pelayanan.

Sejalan dengan itu, maka pemerintah desa adalah sarana untuk menata dan mengelola administrasi desa, karena dengan pengelolaan administrasi desa secara efektif akan membawa perubahan besar terhadap pemerintahan desa. Tata kelola administrasi desa kedengarannya simple, tapi ini kemudian punya peran penting dalam implementasi sebuah kebijakan yang ada didesa. Tata kelola administrasi desa yang baik dan benar akan menjadi faktor penunjang pembangunan desa terhadap kemasyalatan serta kesejatraan rakyat. Begitupulah sebaliknya, jika pemerintah tidak dengan bijak mengelola serta menata administrasi desa, maka akan menjadi patologi tersendiri terhadap kemajuaan suatu desa (Trisno Mais, dkk, TT: 2).

Jenis dan bentuk Administrasi Desa menurut Peraturan Menteri Dalam Negeri Nomor 32 Tahun 2006 (dalam Ulima Islami, 2016), yaitu: 1) Administrasi umum, 2) Administrasi penduduk, 3) Administrasi keuangan, 4) Administrasi pembangunan, 5) Administrasi Badan Permusyawaratan Desa (BPD), dan 6) Administrasi lainnya. Kaitannya dengan pengembangan desa inovatif yang berbasis riset dan pengembangan ini, secara administratif akan dikelola dan dikawal pada bidang administrasi pembangunan. Di dalam pengelolaan administrasi pembangunan ini, hasil riset tersebut dapat dikempas pada pada Buku Administrasi Pembangunan, misalnya yang terdiri dari: 1) Buku Rencana Pembangunan, 2) Buku Kegiatan Pembangunan, 3) Buku Inventaris Proyek; dan 4) Buku Kader-Kader Pembangunan/Pemberdayaan Masyarakat.

Kaur Pembangunan dengan demikian memiliki fungsi yang lebih dalam mengembangkan potensi desa dengan menggunakan hasil riset. Hal ini tentunya disebabkan tugas dan fungsi yang diemban oleh kaur pembangunan tersebut dalam tugas pokoknya yaitu "membantu Kepala 
Desa dalam melaksanakan penyiapan bahan perumusan kebijakan teknis pengembangan ekonomi masyarakat dan potensi desa, pengelolaan administrasi pembangunan, pengelolaan pelayanan masyarakat serta penyiapan bahan usulan kegiatan dan pelaksanaan tugas pembantuan. Disamping itu, guna mengembangkan hasil riset, Kesra juga memiliki bagian di dalamnya, terutama sekali dalam hal melaksanakan program pemberdayaan masyarakat dan sosial masyarakat.

Menurut Sunartiningsih (Sukmana, 60: 2010), pemberdayaan masyarakat diartikan sebagai upaya untuk membantumasyarakat dalam mengembangkan kemampuan sendiri sehingga bebas dan mampu untuk mengatasi masalah dan mengambil keputusan secara mandiri. Dengan demikian pemberdayaan masyarakat ditujukan untuk mendorong terciptanya kekuatan dan kemampuan lembaga masyarakat untuk secara mandiri mampu mengelola dirinya sendiri berdasarkan kebutuhan masyarakat itu sendiri, serta mampu mengatasi tantangan persoalan di masa yang akan datang.

Lebih dari itu, partisipasi masyarakat dalam pembangunan merupakan hal yang penting ketika diletakkan atas dasar keyakinan bahwa masyarakatlah yang paling tahu apa yang dibutuhkan. Partisipasi yang hakiki akan melibatkan masyarakat dalam keseluruhan tahapan pengembangan, mulai dari proses perencanaan, pengambilan keputusan, dan pengawasan program pengembangan desa (Dewi, 2013: 134).

Apabila masyarakat sudah diberdayakan sesuai dengan fungsinya baik dalam tataran administratif dan faktual, dengan sendirinya akan muncul masyarakat-masyarakat yang kreatif dan inovatif. Namun sekali lagi, untuk menemukan dengan potensi apa masyarakat itu dapat ditemukan keunggulannya berdasarkan latar sosiokultural, sejarah, ekonomi, tingkat pendidikan, status sosial, dan lain sebagainya tidak lain melalui riset atau penelitian, yang dalam hal ini menggunakan research \& development.

\section{Riset dalam Membangun Desa Inovatif}

Menemukan kebanaran tidak saja dapat dilakukan melalui proses penelitian, terdapat beberapa pendekatan unscietific menurt Burhan Bungin (2008) yang sering digunakan, yaitu dengan cara kebetulan, trial and eror (sekedar coba-coba-red), dan melalui otoritas seseorang. Ketiga cara ini tidak cukup epektif untuk mendapatkan kebenaran, apalagi dijadikan sebagai rujukan untuk melaksanakan kebijakan. Maka jelas yang dibutuhkan adalah mencari kebenaran melalui proses penelitian.

Kaitannya dengan pengembangan desa berbasis riset ini, dapat dialakukan dengan beragam pendekatan baik itu kuantitatif atau pun kualitatif. Berikut beberapa contoh penelitian yang bertujuan untuk mengungkap potensi lokal suatu dengan dengan kebijakan pengembangannya. Pertama, hasil penelitian Muhammad Syafi'i dan Djoko Suandono yang berjudul "Perencanaan Desa Wisata Dengan Pendekatan Konsep Community Based Tourism (CBT) Di Desa Bedono, Kecamatan Sayung, Kabupaten Demak". Disamping menemukan dan mengidentitifikasi segala hal yang berkaitan dengan konteks penelitiannya, sekaligus memberikan sekitar 6 (enam) catatan penting bagi pemerintah desa untuk menunjang konsep CBT tersebut. Penelitian ini menggunakan pendekatan kualitatif dengan metode analsis SWOT; kedua, hasil penelitian Dian Purnomi Jati, dkk dengan judul "Model Pengembangan Desa 
Inovatif Desa Kalisari Kabupaten Banyumas", yang menekankan pada usaha mengeksplor usaha kreatif dari pemerintahan desa untuk mempengaruhi masyarakatnya menjadi masyarakat yang inovatif. Disamping itu, karena merupakan penelitian pengembangan, memberikan alternatif dan masukan berdasarkan hasil analisis yang dilakukan, sehingga mampu di praktikkan pada tujuan praktis. Meskipun kedua contoh hasil penelitian ini spasialnya di Jawa, namun tetap sebagai acuan bahwa penelitian dalam pengembangan desa itu sangatlah penting. Di tempat lain, misalnya di Sulawesi juga tidak sedikit contoh hasil penelitian yang dapat dijadikan acuan.

Berangkat dari dua contoh di atas, setidaknya banyak tema yang disesuaikan dengan kebutuhan pengembangan desa dapat di teliti, apakah itu menggunakan jasa lembaga penelitian, perguruan tinggi, atau lembaga riset yang sengaja dibentuk oleh desa guna mendukung pembangunan desa yang berbasis riset.

Contoh di atas, dan kebanyakan hasil penelitian tentang pengelolaan desa hanya sekedar hasil reset yang dilakukan baik untuk menyelesaikan studi bagi mahasiswa baik pada jenjang S1, S2, atau pun S3. Bahkan bias jadi sekedar penelitin bagi dosen yang dibiayai oleh Ristekdikti. Namun jauh dari itu, yang lebih penting adalah adanya inisiatif dari desa untuk memiliki lembaga riset dalam pengembangan desa, seperti "Dewan Riset Desa" yang bekerja dan melalukan penelitian sesuai dengan kebutuhan pengembangan desa.

Berbeda dengan pendekatan yang unscientific seperti dijelaskan sebelumnya, hasil riset paling tidak dapat menjelaskan lebih dalam dan mendetail mengenai apa saja yang dibutuhkan dalam penyelenggaraan pemerintah desa yang lebih sesuai dengan kebutuhan masyarakat sebagai ujung tombak dari pembangunan desa. Apabila demikian, keinginan untuk menciptakan "masyarakat desa yang inovatif" bukan hanya sekedar wacana, namun dapat menjadi suatu kenyataan .

\section{SIMPULAN}

Sejalan dengan adanya otonomi daerah, pemerintah desa diberikan juga kebebasan untuk mengelola potensi lokal di desanya sesuai dengan local genius yang dimiliki. Tujuan akhir dari pengembangan potensi lokal di desa tersebut pada hakikatnya dapat memberikan kesejahteraan pada masyarakat baik dengan diberikan bimbingan dan penyadaran oleh pihak desa, atau adanya usaha dari desa untuk menggugah kesadaran masyarakatnya menjadi masyarakat yang kreatif. Salah satu jalan untuk menemukan potensi lokal dari masyarakat desa tidak lain melalui riset yang mendalam, khususnya dengan menggunakan riset sosial. Hasil riset tersebut kemudian dapat digunakan dalam kehidupan yang praktis guna mengambil kebijakan yang tentunya benarbenar berpihak pada masyarakat yang diteliti tersebut.Apabila masyarakat dengan semua latar belakang baik dalam aspek sosiokultural, wawasan dan paradigmanya maka dengan sendirinya akan dipahami pula menggugah potensinya, sehingga pada akhirnya akan dapat dikembangkan menjadi masyarakat yang inovatif sesuai dengan apa yang diinginkan oleh pelaksana pemerintahan desa. 
40| Jurnal Ad'ministrare: Jurnal Pemikiran Ilmiah dan Pendidikan Administrasi Perkantoran, Vol.4, No.1, 2017

\section{DAFTAR PUSTAKA}

Bungin, Burhan. (2018). Penelitian Kualitatif: Komunikasi, Ekonomi, Kebijakan Publik, dan Ilmu Sosial Lainnya. Jakarta: Kencana.

Dewi, M. H. U. (2013). Pengembangan Desa Wisata Berbasis Partisipasi Masyarakat Lokal di Desa Wisata Jatiluih Tabanan Bali. Jurnal Kawistara, Vol. 3, No. 2, Agsutus 2013. Hlm 117-226.

Indrawan, M. (2016). Pelaksanaan Administrasi Pemerintahan Desa di Desa Loleng Kecamatan Kota Bangun Kabupaten Kutai Kertanegara. eJournal Adminsitrasi Negara, Vol. 4, No. 4, 2016, hlm 5062-5076.

Islami, U. (2016). Kapasitas Aparatur Desa dalam Tata Tertib Administrasi Desa (Studi Kasus di Desa Tiuh Tohou Kecamatan Menggala Kabupaten Tulang Bawang. Skripsi (Tidak diterbitkan): Universitas Lampung Bandar Lampung.

Jati, Dian. P, dkk. (TT). Model Pengembangan Desa Inovatif Desa Kalisari Kabupaten Banyumas. Naskah Publikasi: Universitas Jendral Sudirman.

Mais, Trisno, dkk. (TT). Tata Kelola Administrasi Desa dalam Menyelenggarakan Pemerintahan di Era Otonomi Desa (Studi di Desa Buo Kecamatan Loloda Kabupaten Halmahera Barat. Naskah Publikasi.

Salinan Peraturan Mentri dalam Negeri Republik Indonesia No 1 Tahun 2016 tentang Pengelolaan Aset Desa.

Sukmana, O. (2010). Konsep Pemberdayaan Masyarakat Melalui Pengembangan Komunitas Berbasis Potensi Lokal (Studi di Desa Wisata Bunga Sidomulyo, Kota Batu, Jawa Timur). Jurnal Humanity, Vol. 6, No. 1, September 2010, hlm 95-64.

Syafi'i, M dan Djoko, S. (2015). Perencanaan Desa Wisata Dengan Pendekatan Konsep Community Based Tourism (CBT) Di Desa Bedono, Kecamatan Sayung, Kabupaten Demak. Jurnal Ruang, Vol. 1, No. 2, tahun 2015, hlm 51-60. 